Article

\title{
Compost and Sewage Sludge for the Improvement of Soil Chemical and Biological Quality of Mediterranean Agroecosystems
}

\author{
Enrica Picariello ${ }^{1,2}$, Luca Pucci ${ }^{3}$, Maurizio Carotenuto ${ }^{2}$, Giovanni Libralato ${ }^{4} \mathbb{D}$, Giusy Lofrano 5 \\ and Daniela Baldantoni ${ }^{2, * \mathbb{D}}$
}

1 Department of Sciences and Technologies, University of Sannio, 82100 Benevento, Italy; enrytwin@gmail.com

2 Department of Chemistry and Biology "Adolfo Zambelli", University of Salerno, 84084 Fisciano (SA), Italy; mcarotenuto@unisa.it

3 Gori Spa, 80056 Ercolano (NA), Italy; lpucci@goriacqua.com

4 Department of Biology, University of Naples Federico II, 80126 Napoli, Italy; giovanni.libralato@unina.it

5 Centro Servizi Metrologici e Tecnologici Avanzati (CeSMA), Complesso Universitario di Monte Sant'Angelo, 80126 Napoli, Italy; giusylofrano@gmail.com

* Correspondence: dbaldantoni@unisa.it; Tel.: +39-089-969542

Citation: Picariello, E.; Pucci, L.; Carotenuto, M.; Libralato, G.;

Lofrano, G.; Baldantoni, D. Compost and Sewage Sludge for the Improvement of Soil Chemical and Biological Quality of Mediterranean Agroecosystems. Sustainability 2021, 13, 26. https://dx.doi.org/10.3390/ su13010026

Received: 28 November 2020 Accepted: 18 December 2020 Published: 22 December 2020

Publisher's Note: MDPI stays neutral with regard to jurisdictional claims in published maps and institutional affiliations.

Copyright: () 2020 by the authors. Licensee MDPI, Basel, Switzerland. This article is an open access article distributed under the terms and conditions of the Creative Commons Attribution (CC BY) license (https: / / creativecommons.org / licenses/by/4.0/).

\begin{abstract}
Conventional fertilization practices in agroecosystems concern the supply of bioavailable nutrients, such as mineral fertilizers. A consolidated alternative to restoring the long-term fertility of agricultural soils is their amendment with organic fertilizers. Soil amendment with biowaste compost or sewage sludge represents a sustainable strategy to avoid the landfilling of organic matter derived from urban waste and sewage sludge. This study aims at validating the use of quality biowaste compost and sewage sludge from secondary sedimentation (alone or in combination with mineral fertilizers) in a Mediterranean agroecosystem and their effects on soil chemical and biological quality, with a view to verifying the maintenance of soil fertility and functionality. In particular, the dynamics of soil organic matter, $\mathrm{pH}$, potentially toxic elements and microbial community functionality were assessed, in experimental mesocosms, during 6 months of incubation. The research showed that, while soil amendment with biowaste compost induces positive effects on soil organic matter and phosphorous concentrations, as well as on microbial community functionality, the amendment with the selected sewage sludge does not determine any benefit to the microbial community or any danger in relation to soil potentially toxic element concentrations and toxicity. The quantity of sewage sludge employed, chosen according to regional directives, was thus not enough to stimulate the edaphic microflora activity.
\end{abstract}

Keywords: sewage sludge; biowaste compost; mineral and organic fertilization; physico-chemical and biological soil properties; toxicity

\section{Introduction}

Soil organic matter (SOM) plays a major role at the global level in the context of climate change [1]. A loss of soil organic carbon (SOC) contributes not only to a reduction of soil productivity, but also to climate change, since the carbon is partly lost through $\mathrm{CO}_{2}$ emissions [2]. SOM indirectly contributes to agro-ecosystem productivity and to food security, maintaining the fertility of cultivated soils, providing energy for edaphic microorganisms that allow the functioning of agroecosystems [3], and making inorganic and organic pollutants less available [4,5]. Thus, there is the need to implement management options that allow enhancing soil fertility and increasing SOC stocks, contributing also to climate change mitigation. Especially within the Mediterranean area, facing a high risk of desertification, the increase in SOC is pivotal in counteracting the current trends of soil erosion and loss of fertility with the consequent long-term effects on ecosystem viabilities [6]. 
The use of soil organic amendments, such as biowaste compost (BC) or sewage sludge (SS), is a sustainable agricultural practice presenting two advantages: on the one hand, it supplies valuable nutrients (e.g., nitrogen and phosphorus) and organic matter to agricultural soil, and on the other hand, it allows the reutilization of by-products of waste treatment plants. Compost addition is the most employed land management practice for the accumulation of organic carbon in soils [7,8], while providing plants with essential nutrients [9-11]. Long-term soil amendments with biowaste compost, alone or in combination with mineral fertilizers (MFs), may represent a cost-effective, eco-friendly, and safe strategy [12,13]. Indeed this practice not only can have positive effects on crop yield [8] and edaphic community $[14,15]$, but also can ensure crop quality [12,16], even when increase in soil potentially toxic element (PTE) bioavailability occur [17]. The physicochemical and biological properties of agroecosystem soils may be improved not only by BC, but also by SS application. The organic matter (OM) contained in SS can improve the soil physical properties, such as soil aeration and water holding capacity [18,19], increasing the availability of limiting elements such as phosphorus $(\mathrm{P})$ with positive effects on crop yield [20]. Nevertheless, organic amendments can contain undesirable components such as non-essential elements and pathogens, affecting on a one-health basis both humans and the environment $[15,21]$. PTEs (and several chemical compounds) can affect soil microbial communities and, in turn, soil functionality and fertility [22,23]. The study of microbiological properties of agricultural soil is of great importance in highlighting the overall soil quality and the stabilization and degradation of SOM, which can contribute to soil $\mathrm{CO}_{2}$ emissions and loss of soil carbon stocks [24].

The agricultural use of organic amendments in Italy is regulated by Legislative Decree 75, 2010 [25]. At the European level, the EU regulation [26] on SS application establishes regulatory guidelines to prevent potential damages to the environment and human health, and sets limit values for heavy metal concentrations. However, the legislation on the use of SS in agriculture is scantly developed in Italy [27]. Since the quality of the sludge produced depends on several factors extremely variable along the peninsula (type of waste entering treatment plants, different customs of Italian citizens, productive realities present in the territory, collection and management of the waste cycle), it is not possible to establish a unique guideline for all regions, and several regional guidelines have been recently implemented.

In order to verify the maintenance/increase of soil fertility and functionality that we expected from the use of sewage sludge and biowaste compost (alone or in combination with mineral fertilizers), this study compared the chemical and biological effects of different fertilization practices in soil mesocosms simulating Mediterranean agroecosystems. Soil $\mathrm{OM}$ and PTE concentrations, microbial $\mathrm{C}$ and $\mathrm{N}$ concentrations, enzymatic activities (hydrolytic, $\beta$-glucosidase and phosphatase), microbial respiration and biomass, and toxicity trends were followed for 6 months. Our strategy included two main goals: (1) the characterization of SOM and PTE concentrations following different fertilization practices, and (2) the monitoring of the effects of SS or BC on soil microbial biomass and enzymatic activities. In particular, soil microbial parameters, which provide information on the biomass, activity and diversity of soil microbial communities, are often used as biological indicators of the impact of disturbances (e.g., agricultural practices, contamination) on soil quality [22] due to their sensitivity, fast response and ecological relevance [28-30].

\section{Materials and Methods}

\subsection{Soil Sampling and Mesocosm Set-Up}

From an agricultural Mediterranean area $(40.764082 \mathrm{~N}, 14.658414 \mathrm{E})$ in the Campania region (southern Italy) $120 \mathrm{~kg}$ of soil was sampled (0-10 cm depth), homogenized and divided in 6 aliquots for differential treatments (three mesocosm replicates per treatment; $6 \mathrm{~kg}$ f.w. soil for each mesocosm). The 6 exposure conditions included the following scenarios (Table S1): (1) untreated reference soil (UNT), (2) soil amended with BC (CMP); (3) soil amended with SS (FNG), (4) soil amended with mineral NPK fertilizer (MIN), 
(5) soil treated with BC and MF at half doses of those supplied in CMP and MIN treatments $(\mathrm{C}+\mathrm{M})$, and (6) soil treated with SS and MF at half doses of those supplied in FNG and MIN treatments $(\mathrm{F}+\mathrm{M})$.

CMP treatment was obtained adding to each mesocosm $494 \mathrm{~g}$ of BC (Table 1 and Table S1) produced by the Salerno (Italy) composting plant, from solid organic wastes and urban greening, in order to reach a final dose of $30 \mathrm{t} / \mathrm{ha}$; this treatment often demonstrated to be the most advantageous in the Mediterranean area for edaphic community [31], as well as for crop yield and quality $[8,17,18]$. FNG treatment was obtained by adding to each mesocosm $987.5 \mathrm{~g}$ of SS (Table 1 and Table S1) produced by the Nocera Superiore (southern Italy) urban wastewater treatment plant (UWWTP), taking into account the quantity ( $5 \mathrm{t} / \mathrm{ha}$ ) suggested by the regional legislation for the use of SS [32], as reported in the ISPRA Lombardia report [33]. In MIN treatment, the quantity (6.6 g) of MF (Table 1 and Table S1) added to each mesocosm was calculated taking into account the doses recommended by the manufacturer (Azovel Universale_Linfa SpA).

Table 1. Physico-chemical properties (when available) of biowaste compost (BC), sewage sludge (SS) and mineral fertilizer (MF) employed in setting up the mesocosms.

\begin{tabular}{|c|c|c|c|}
\hline Physico-Chemical Property & BC & SS & MF \\
\hline $\mathrm{pH}$ & 7.7 & 7.8 & \\
\hline Organic C (\% d.m.) & 30.0 & 24.8 & \\
\hline Total N (\% d.m.) & 2.61 & 1.30 & 12 \\
\hline Organic N (\% total N) & 96.6 & & \\
\hline Nitric N (\% d.m.) & & & 7.5 \\
\hline Ammoniacal N (\% d.m.) & & & 4.5 \\
\hline $\mathrm{C} / \mathrm{N}$ & 12 & & \\
\hline Humic and fulvic acids (\% d.m.) & 11.9 & & \\
\hline Total P (\% d.m.) & 0.57 & 0.30 & \\
\hline $\mathrm{P}_{2} \mathrm{O}_{5}$ (\% d.m.) & & & 10 \\
\hline Total K ( $\mu \mathrm{g} / \mathrm{g}$ d.m.) & 0.02 & 0.40 & \\
\hline $\mathrm{K}_{2} \mathrm{O}$ (\% d.m.) & & & 18 \\
\hline $\mathrm{SO}_{3}$ (\% d.m.) & & & 37 \\
\hline Total Cd ( $\mu$ g/g d.m.) & 37.95 & 11.14 & \\
\hline Total Cu ( $\mu \mathrm{g} / \mathrm{g}$ d.m.) & 147.91 & 297.44 & \\
\hline Total Ni ( $\mu \mathrm{g} / \mathrm{g}$ d.m.) & 22.40 & 66.80 & \\
\hline Total Mn ( $\mu \mathrm{g} / \mathrm{g}$ d.m.) & 167.12 & 189.58 & \\
\hline Total $\mathrm{Pb}$ ( $\mu \mathrm{g} / \mathrm{g}$ d.m.) & bdl & 0.20 & \\
\hline Total V ( $\mu \mathrm{g} / \mathrm{g}$ d.m.) & 23.41 & 121.02 & \\
\hline Total Zn ( $\mu$ g/g d.m.) & 208.40 & 107.23 & \\
\hline
\end{tabular}

bdl = below detection limit.

Mesocosms $(20 \times 30 \times 10 \mathrm{~cm}$ each $)$ were incubated in the dark at controlled temperature $\left(18 \pm 2{ }^{\circ} \mathrm{C}\right)$ and relative humidity $(81 \pm 10 \%)$, and once a week irrigated with $500 \mathrm{~mL}$ of distilled water. Soil organic matter, microbial $\mathrm{C}$ and $\mathrm{N}$ concentrations, total PTE concentrations and $\mathrm{pH}$, as well as soil enzymatic activities (hydrolytic, $\beta$-glucosidase and phosphatase), microbial respiration and biomass were monitored every month for 6 months. To this end, 6 soil sub-samples were collected from the 3 mesocosms with the same treatment and pooled for the subsequent analyses.

\subsection{Soil Physico-Chemical and Microbiological Analyses}

Analyses were carried out in triplicates per soil treatment on sieved $(2 \mathrm{~mm})$ samples. Physico-chemical parameters were analyzed on dry soil, whereas biological parameters were analyzed on fresh soil after water content characterization.

Soil water content (after oven-drying at $105{ }^{\circ} \mathrm{C}$ for $48 \mathrm{~h}$ ), and $\mathrm{OM}$ concentration (calcination in muffle, at $550{ }^{\circ} \mathrm{C}$ for $4 \mathrm{~h}$, Nabertherm $\mathrm{GmbH}$, Controller B 170) were determined using gravimetric methods. Total PTE $(\mathrm{Cu}, \mathrm{Mn}, \mathrm{Ni}, \mathrm{P}, \mathrm{V}, \mathrm{Zn})$ concentrations were determined as reported in Baldantoni et al. (2016) [17]. 
Soil $\mathrm{pH}$ was determined via potentiometric method (Mettler Toledo, Five-Go) in a distilled water suspension (1:50, $w: w$ soil:water).

Microbial biomass was determined measuring microbial $\mathrm{C}$ and $\mathrm{N}$ concentrations (Shimadzu V-CNS TOC analyzer) through the fumigation-extraction method [34].

Fluorescein diacetate hydrolytic activity was determined by Schnurer and Rosswall's (1982) method [35]. Phosphatase activity was determined by Doran et al.'s (1996) method [36] and $\beta$-glucosidase activity by Rodríguez-Loinaz et al.'s (2008) method [37]. Spectrophotometric measurements were carried out by a Shimadzu UV-1800 UV/Vis spectrophotometer. Microbial respiration was determined as reported in Iovieno et al. (2009) [31], measuring the $\mathrm{CO}_{2}$ released during incubation by gas chromatography (GS 6850, Agilent Technologies, CA, USA), and microbial biomass was obtained by Vance et al.'s (1987) method [34].

\subsection{Toxicity Testing}

Toxicity testing was carried out in triplicate on eluates (Solid/Liquid ratio (S/L) $=1: 10)$ under mechanical agitation after dry weight determination $\left(105^{\circ} \mathrm{C}\right.$ for $\left.48 \mathrm{~h}\right)$ of samples from month 2 to month 6 (due to the lack of enough soil material for month 1), according to EN (2002) [38]. Bioassays included the growth inhibition test (72 h) with Raphidocelis subcapitata [39], the germination index (72 h) with Lepidium sativum [40] and the immobilization test (48 h) with Daphnia magna [41]. Reconstructed freshwater according to ISO (2012) [41] was used as the eluting medium. Whole eluate samples were investigated, and results expressed as the percentage of effect (\%) after normalization on negative controls according to Abbott's formula.

\subsection{Statistical Analysis}

Data analysis was performed in the $\mathrm{R}$ 3.4.3 programming environment using the "stats", "vegan" and "agricolae" packages [42]. The overall differences among treatments and over time, based on the determined chemical, physical and biological parameters, were evaluated through two-way multivariate analysis of variance (MANOVA). In order to evaluate the multivariate separation of the groups defined by soil treatments, and to understand which variables contributed the most to the possible differences, the non-metric multidimensional scaling (NMDS), with the superimposition of the confidence ellipses (for $\alpha=0.05$ ) for the treatments and of the time gradient was applied. The significance of the differences in each chemical, physical, biological and ecotoxicity parameter among the treatments and along time were evaluated by two-way analyses of variance (ANOVAs), followed by Tukey post hoc tests (for $\alpha=0.05$ ). Before ANOVAs, data were tested for normality and homoscedasticity through Shapiro and Bartlett tests, respectively. Correlations among the biological parameters and each PTE analyzed were evaluated by the Pearson's test.

\section{Results}

The MANOVA highlighted significant differences among the treatments $(\mathrm{F}=3.77$, $p<0.001)$ and sampling times $(\mathrm{F}=32.55, p<0.001)$. The NMDS with the superimposition of confidence ellipses (Figure 1) clearly separated CMP and partly $\mathrm{C}+\mathrm{M}$ treatments from the others (FNG, F + M, MIN and UNT), with soil respiration, hydrolase activity, and microbial $C$ and $\mathrm{N}$ relatively more abundant in mesocosms amended with $\mathrm{BC}$. The same parameters were more abundant in the first months of incubation. 


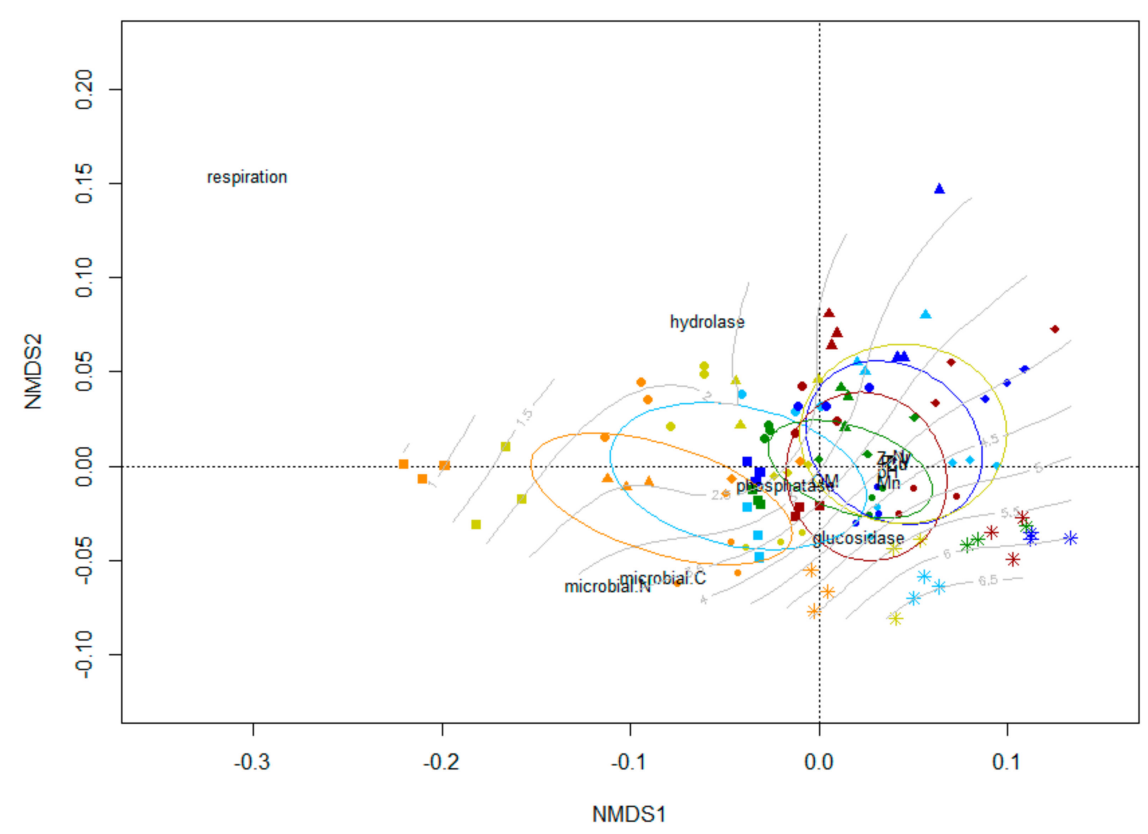

Figure 1. Non-metric multidimensional scaling (NMDS) biplot showing the differentiation among soil treatments in relation to parameters measured, with superimposition of confidence ellipses (for $\alpha=0.05$ ) and the time gradient. Observations are coded in relation to the treatment (UNT: dark red, CMP: orange, $\mathrm{C}+\mathrm{M}$ : light blue, FNG: dark green, F + M: dark blue, MIN: light green), and to time (1 month: square, 2 months: large circle, 3 months: triangle, 4 months: diamond, 5 months: small circle, 6 months: star).

Organic matter (Figure 2, Table 2) maintained similar values along the incubation period in all the treatments, with a significant $(p<0.001)$ decrease after 5 months. The highest organic matter content was found in the CMP followed by the $\mathrm{C}+\mathrm{M}$ treatment, with an average value of 6.4 and 5.7\% d.w., respectively. FNG, F + M and MIN did not show significant differences with UNT; after six months, UNT contained the lowest amount of organic matter ( $4.8 \%$ d.w.), whereas F + M, FNG and MIN reached a comparable organic matter value of around $4.5 \%$ d.w.

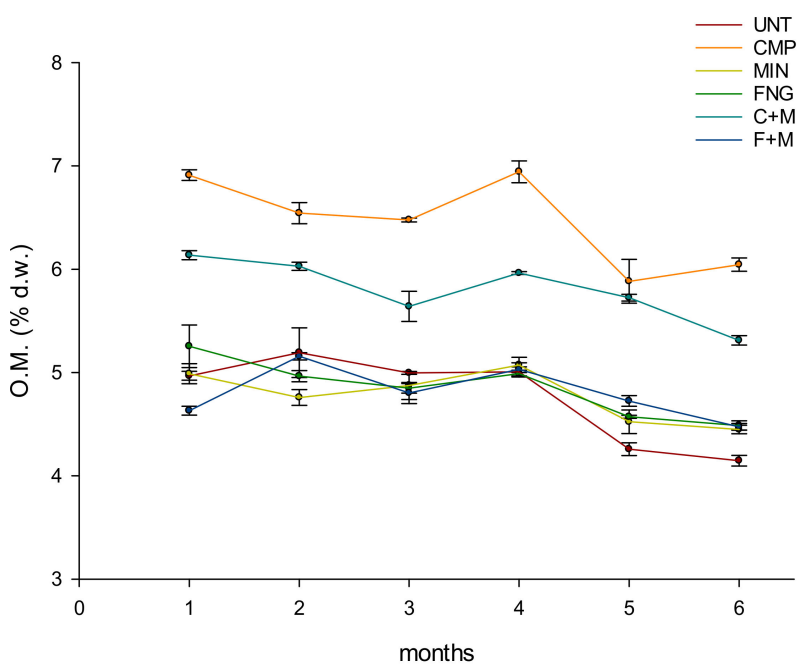

Figure 2. Mean concentrations of organic matter in untreated soil (UNT), and in soils treated with biowaste compost (CMP), sewage sludge (FNG), compost plus mineral fertilizer $(C+M)$, sewage sludge plus mineral fertilizer $(F+M)$ and mineral fertilizer (MIN) during 6 months of incubation. The error bars represent the standard deviations. 
Table 2. Two-way ANOVA F-values evaluated for the organic matter content, respiration, enzymatic activities and microbial $\mathrm{C}$ and $\mathrm{N}$ concentrations. The $\mathrm{q}$ coefficients of the post hoc tests of Tukey (for $\alpha=0.05$ ) performed for the treatment (UNT $=$ untreated soil, $\mathrm{CMP}=$ soil treated with biowaste compost, FNG = soil treated with sewage sludge, $\mathrm{C}+\mathrm{M}=$ soil treated with compost plus mineral fertilizer, $\mathrm{C}+\mathrm{F}=$ soil treated with sewage sludge plus mineral fertilizer, MIN = soil treated with mineral fertilizer) factor are also shown. The asterisks indicate the $p$-value $\left({ }^{* * *} p<0.001,{ }^{* *} p<0.01,{ }^{*} p<0.05\right)$.

\begin{tabular}{|c|c|c|c|c|c|c|c|}
\hline Comparison & OM & Respiration & Hydrolase & $\beta$-glucosidase & Phosphatase & Microbial C & Microbial N \\
\hline \multicolumn{8}{|l|}{ Two way ANOVA } \\
\hline treatment & $355.9^{* * *}$ & $1040^{* * *}$ & $20.41^{* * *}$ & $31.08^{* * *}$ & $143.5^{* * *}$ & $85.419 * * *$ & $94.335 * * *$ \\
\hline time & $52.17^{* * *}$ & $1645^{* * *}$ & $69.95^{* * *}$ & $184.5^{* * *}$ & $53.06^{* * *}$ & $60.696^{* * *}$ & $114.875^{* * *}$ \\
\hline treatment $\times$ time & $3.61^{* * *}$ & $298.85^{* * *}$ & $4.87^{* * *}$ & $7.31^{* * *}$ & $4.29 * * *$ & $6.491^{* * *}$ & $7.075^{* * *}$ \\
\hline \multicolumn{8}{|l|}{$\begin{array}{l}\text { Tukey (comparison } \\
\text { for factor treatment) }\end{array}$} \\
\hline CMP vs. UNT & $44.625^{* * *}$ & $71.605^{* * *}$ & $12.759 * * *$ & $12.658^{* * *}$ & $27.333^{* * *}$ & $20.002 * * *$ & $17.028 * * *$ \\
\hline CMP vs. MIN & $44.154^{* * *}$ & $74.596^{* * *}$ & $7.847^{* * *}$ & $11.801^{* * *}$ & $30.141^{* * *}$ & $24.041^{* * *}$ & $25.162 * * *$ \\
\hline $\mathrm{CMP}$ vs. $\mathrm{F}+\mathrm{M}$ & $42.935^{* * *}$ & $68.651^{* * *}$ & $8.64^{* * *}$ & $8.554^{* * *}$ & $29.538^{* * *}$ & $23.358^{* * *}$ & $24.267^{* * *}$ \\
\hline CMP vs. FNG & $41.319^{* * *}$ & $73.351^{* * *}$ & $6.898^{* * *}$ & $5.548 * *$ & $24.666^{* * *}$ & $20.564^{* * *}$ & $218.724^{* * *}$ \\
\hline $\mathrm{CMP}$ vs. $\mathrm{C}+\mathrm{M}$ & $16.408^{* * *}$ & $22.53^{* * *}$ & 2.747 & 0.0147 & $12.807^{* * *}$ & $11.782 * * *$ & $8.532 * * *$ \\
\hline $\mathrm{C}+\mathrm{M}$ vs. UNT & $28.216^{* * *}$ & $49.076^{* * *}$ & $10.011^{* * *}$ & $12.643^{* * *}$ & $14.525^{* * *}$ & $8.220 * * *$ & $8.497^{* * *}$ \\
\hline $\mathrm{C}+\mathrm{M}$ vs. MIN & $27.745^{* * *}$ & $52.066^{* * *}$ & $5.1^{* *}$ & $11.786^{* * *}$ & $17.333^{* * *}$ & $12.259 * * *$ & $16.630^{* * *}$ \\
\hline $\mathrm{C}+\mathrm{M}$ vs. $\mathrm{F}+\mathrm{M}$ & $26.527^{* * *}$ & $46.121^{* * *}$ & $5.893^{* * *}$ & $8.539^{* * *}$ & $16.73^{* * *}$ & $11.576^{* * *}$ & $15.736^{* * *}$ \\
\hline $\mathrm{C}+\mathrm{M}$ vs. FNG & $24.911^{* * *}$ & $50.821 * * *$ & 4.151 * & $5.533 * *$ & $11.858^{* * *}$ & $8.782 * * *$ & $10.193^{* * *}$ \\
\hline FNG vs. UNT & 3.305 & 1.745 & $5.861^{* * *}$ & $7.11^{* * *}$ & 2.667 & 0.562 & 1.696 \\
\hline FNG vs. MIN & 2.835 & 1.245 & 0.949 & $6.253^{* * *}$ & $5.475^{* *}$ & 3.477 & $6.438^{* * *}$ \\
\hline FNG vs. $F+M$ & 1.616 & $4.699^{* *}$ & 1.742 & 3.006 & $4.872 *$ & 2.794 & $5.543 * *$ \\
\hline $\mathrm{F}+\mathrm{M}$ vs. UNT & 1.689 & 2.954 & 4.118 & 4.104 & 2.205 & 3.356 & $5.095 * *$ \\
\hline $\mathrm{F}+\mathrm{M}$ vs. MIN & 1.219 & $5.945^{* * *}$ & 0.793 & 3.247 & 0.603 & 0.683 & 1.696 \\
\hline MIN vs. UNT & 0.471 & 2.991 & 4.911 * & 0.857 & 2.808 & 0.060 & $8.134^{* * *}$ \\
\hline
\end{tabular}

All the biological parameters showed significant differences among treatments $(p<0.001)$ and sampling times $(p<0.001)$, as well as for sampling time $\mathrm{x}$ treatment interactions (Table 2). Microbial C and N (Figure 3, Table 2) showed significantly $(p<0.001)$ higher concentrations in $\mathrm{CMP}$ and $\mathrm{C}+\mathrm{M}$ throughout the incubation period; for the two parameters, FNG, F + M and MIN did not show differences with UNT. Whereas microbial C reached comparable values in the six mesocosm types at the end of incubation (on average $180 \mu \mathrm{g} \mathrm{C} / \mathrm{g}$ soil d.w.), microbial $\mathrm{N}$ still showed significant differences among treatments after six months from incubation. Soil respiration (Figure 4, Table 2) followed the same trend of soil organic matter and microbial $\mathrm{C}$ and $\mathrm{N}$ in relation to soil treatments, showing a significantly $(p<0.001)$ higher rate in CMP and C + M treatments, with average values of 229.4 and $177.1 \mu \mathrm{g} \mathrm{CO} / \mathrm{g}$ soil d.w. h, respectively. A strong decrease in respiration of soils amended with $\mathrm{BC}$ was observed until the third month of incubation, when it reached values comparable to those of the other treatments. After one month, FNG, F+ M and MIN showed values higher than UNT, but over the remaining incubation period the four mesocosm types did not show significant differences, assuming comparable values at the end of incubation: $4.2 \mu \mathrm{g} \mathrm{CO} 2 / \mathrm{g}$ soil d.w. h, on average. Hydrolase activity (Figure $5 \mathrm{a}$, Table 2), at the first month of incubation, showed significant $(p<0.001)$ differences among treatments, reaching comparable values (on average $0.41 \mathrm{mg} \mathrm{FDA} / g$ soil d.w. h) up to the third month. A significant $(p<0.001)$ decrease was observed from the third month of incubation, regardless of the treatment. In addition, from the third month to the end of the incubation, UNT showed the lowest values, whereas CMP and C+M maintained the highest values, with an average value of $0.25 \mathrm{mg}$ FDA/g soil d.w. $\mathrm{h} . \beta$-glucosidase activity (Figure $5 \mathrm{~b}$, Table 2 ) showed the same trend in all the treatments along time, with a significant $(p<0.001)$ decrease until the third month of incubation. In particular, a reduction of 2-fold for UNT, 2-fold for FNG, 1.7-fold for MIN, C + M and F + M, and 1.5 for CMP, compared to the beginning of the incubation, was observed. The activity increased again until the fourth month. At each sampling time (except the first and third months), CMP 
and $\mathrm{C}+\mathrm{M}$ showed the highest values (on average $16 \mu \mathrm{g}$ PNF/g soil d.w.), F + M and FNG assumed comparable values after 1 and 3 months, while they assumed values comparable to MIN and UNT at the end of incubation (with an average $\beta$-glucosidase activity value of $13 \mu \mathrm{g}$ PNF/g soil d.w.). Phosphatase activity (Figure 5c, Table 2) decreased along time in all treatments, and the mean values generally followed the order $\mathrm{CMP}>\mathrm{C}+\mathrm{M}>\mathrm{FNG}=\mathrm{F}$ $+\mathrm{M}=\mathrm{MIN}=\mathrm{UNT}$.
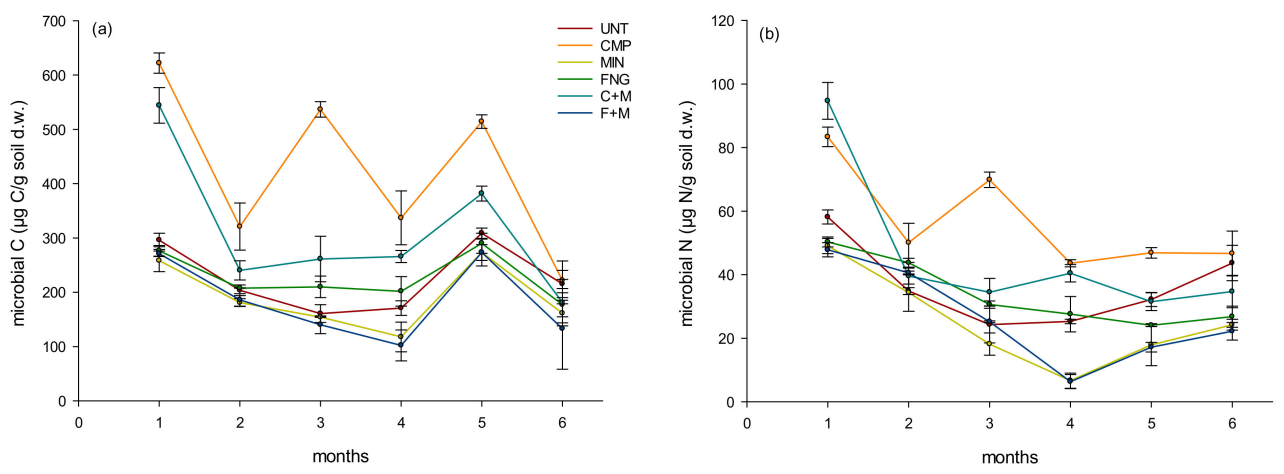

Figure 3. Mean values of (a) microbial $\mathrm{C}$ and (b) microbial $\mathrm{N}$ in untreated soil (UNT), and in soils treated with biowaste compost (CMP), sewage sludge (FNG), compost plus mineral fertilizer (C+ $\mathrm{M})$, sewage sludge plus mineral fertilizer $(\mathrm{F}+\mathrm{M})$ and mineral fertilizer (MIN) during 6 months of incubation. The error bars represent the standard deviations.

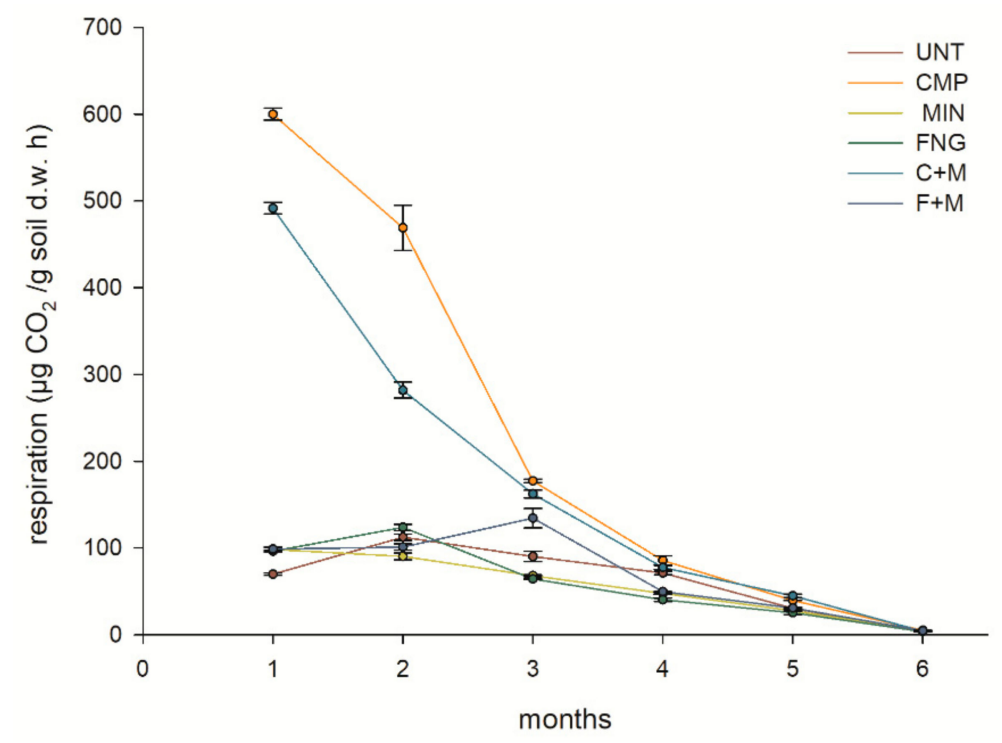

Figure 4. Mean values of soil respiration in untreated soil (UNT), and in soils treated with biowaste compost (CMP), sewage sludge (FNG), compost plus mineral fertilizer $(C+M)$, sewage sludge plus mineral fertilizer $(\mathrm{F}+\mathrm{M})$ and mineral fertilizer $(\mathrm{MIN})$ during 6 months of incubation. The error bars represent the standard deviations. 

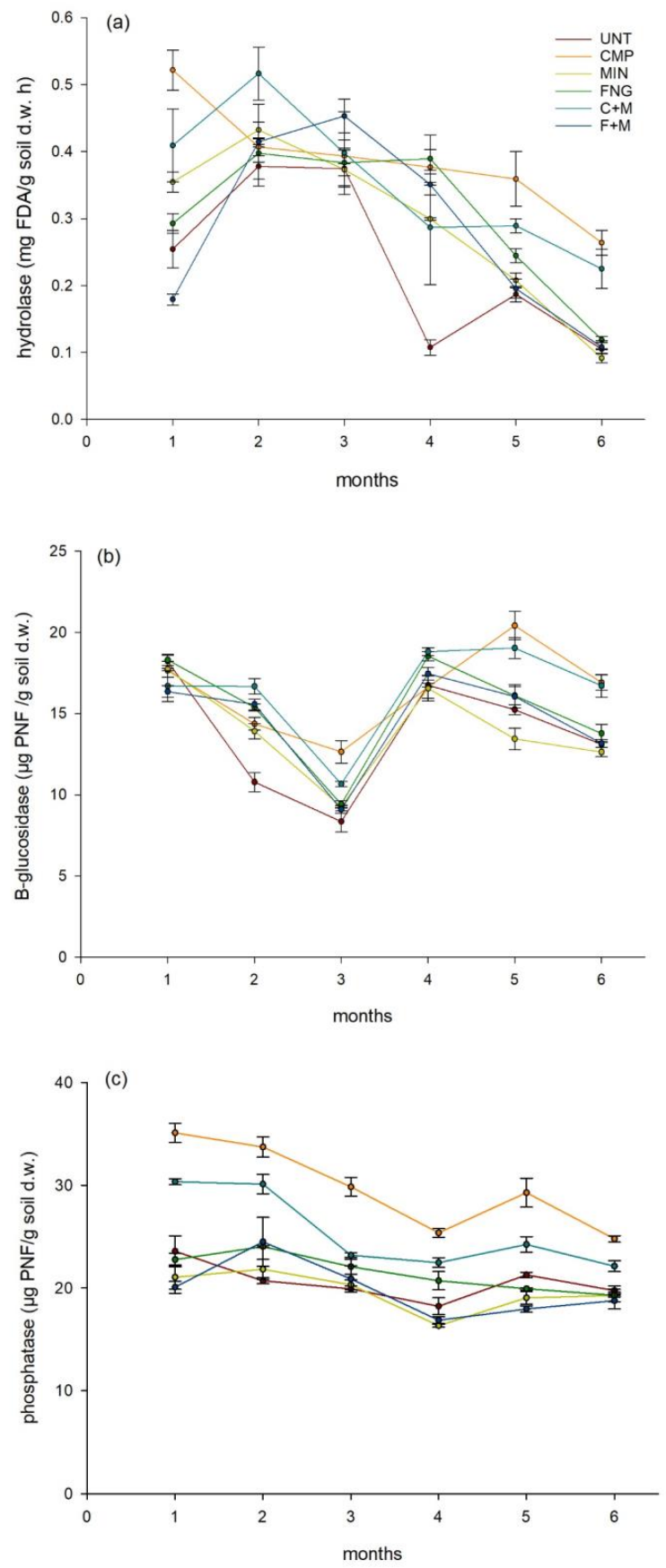

Figure 5. Mean values of (a) hydrolase activity, (b) $\beta$-glucosidase activity and (c) phosphatase activity in untreated soil (UNT), and in soils treated with biowaste compost (CMP), sewage sludge (FNG), compost plus mineral fertilizer $(C+M)$, sewage sludge plus mineral fertilizer $(F+M)$ and mineral fertilizer (MIN) during 6 months of incubation. The error bars represent the standard deviations.

$\mathrm{pH}$ values (Figure S1) showed significant $(p<0.001)$ differences among treatments and sampling times, with average values higher in UNT than in the other treatments. All total PTE concentrations (Figure S2) showed significant $(p<0.001)$ differences along time; significant $(p<0.001)$ differences among treatments were observed only for $\mathrm{P}$ and Ni concentrations, with higher values in CMP and $\mathrm{C}+\mathrm{M}$ soils in respect to the other treatments for $\mathrm{P}$, and highest values in $\mathrm{F}+\mathrm{M}$ soil, at the beginning of incubation, for $\mathrm{Ni}$.

Positive correlations were found between $\mathrm{Cu}, \mathrm{Mn}, \mathrm{P}$ and $\mathrm{Zn}$ and soil respiration, between Mn, P and Zn and hydrolase activity, and between P and Zn concentrations and 
phosphatase activity. Negative correlations were observed between $\mathrm{Ni}$ and microbial C, and between $\mathrm{V}$ and microbial C and N (Table S2).

Results from toxicity testing and relevant statistics were summarized in Figure 6 for R. subcapitata, L. sativum and D. magna. During the experimental period, the toxicity results for all testing species did not significantly change except for $R$. subcapitata (i.e., CNT, $\mathrm{CMP}, \mathrm{C}+\mathrm{M}$, and $\mathrm{F}+\mathrm{M}$ ). The germination index values from $L$. sativum always ranged for all treatment conditions between $80 \%$ and $120 \%$, suggesting that neither inhibition nor biostimulation effects occurred [43]. The immobilization effect values from $D$. magna were not significantly different (for $\alpha=0.05$ ) from CNT (reference soil); all treatments, and time (i.e., from treatment administration) ranging between $35 \%$ and $75 \%$ of effect. Microalgae evidenced in CNT, $\mathrm{C}+\mathrm{M}$, and $\mathrm{F}+\mathrm{M}$ a decrease of toxicity from month 2 to 6 , keeping not significantly different toxicity values from month 3 to month 6 (effect $<10 \%$ ). Conversely, $R$. subcapitata evidenced in CMP an increase of toxicity from month 5 to 6, keeping not significantly different toxicity values from month 2 to month 5 (effect $<10 \%$ ).
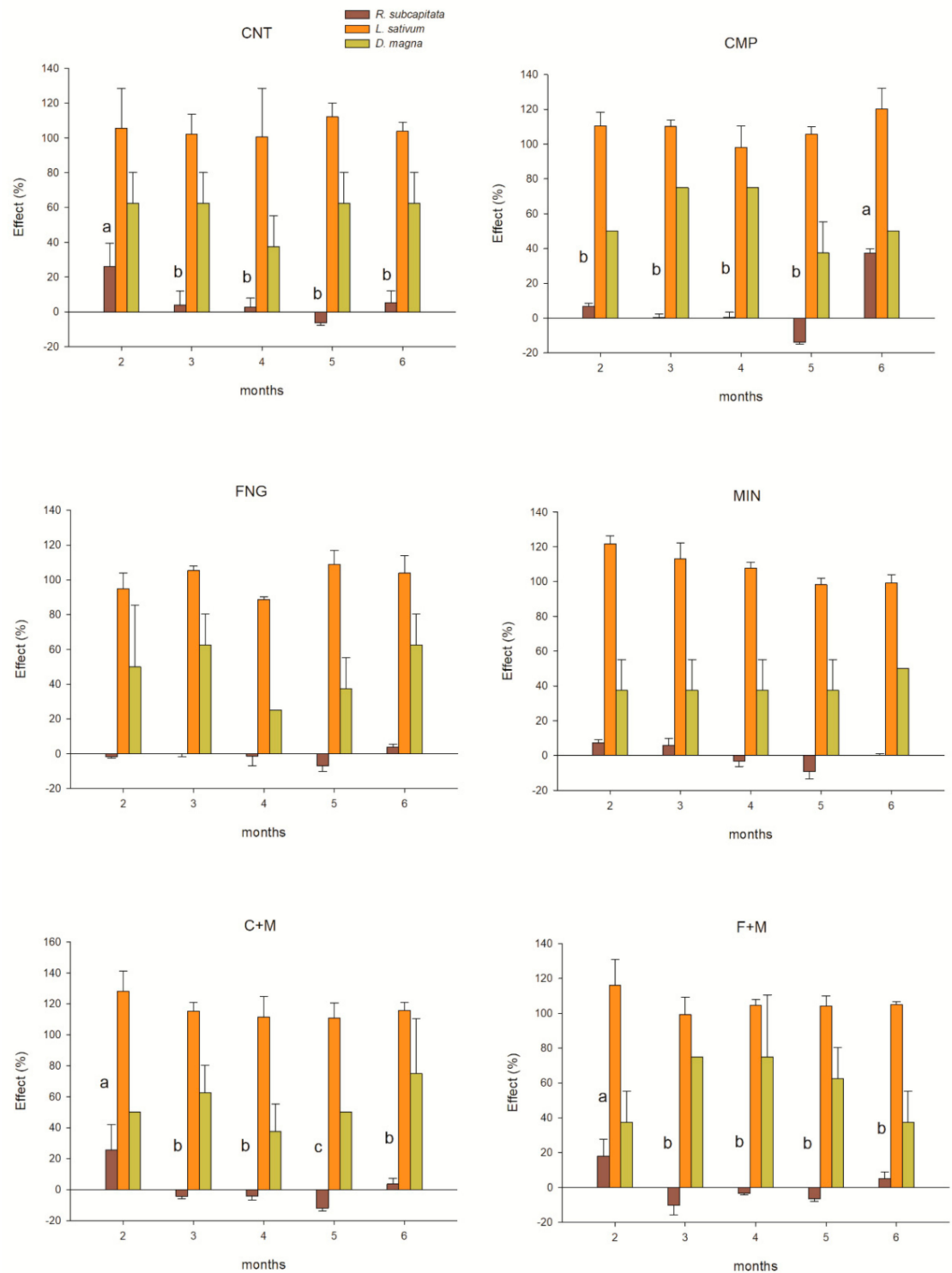

Figure 6. Effect data (\%) for R. subcapitata (\% growth inhibition, 72 h), L. sativum (\% germination index, $72 \mathrm{~h}$ ), and D. magna (\% immobilization, $48 \mathrm{~h}$ ). Data with different letters are significantly different (for $\alpha=0.05$ ) within the same testing species along time. 


\section{Discussion}

The separation of soils amended with biowaste compost from the other treatments, observed in the NMDS space, highlighted that this practice strongly influences the edaphic microbial community. Since microbial parameters possess a high sensitivity and a rapid response, they are important to relieve soil functioning, also in relation to agricultural practices $[23,44]$. In our case, compost amendment favors microbial community, primary in relation to SOM increments. Conversely, SOM losses, observed during the incubation and found in all the treatments, indicate that mineralization processes are mostly controlled by soil conditions rather than the type of organic matter added. The observed increases in SOM attributable to the addition of biowaste compost are also related to increases in microbial biomass, in both microbial $\mathrm{C}$ and $\mathrm{N}$, in respiration rate and in enzymatic activities, suggesting that compost enhances native community and/or brings new microbial biomass to the soil [45].

Contrary to biowaste compost, the amendment with sewage sludge did not determine any benefit to edaphic microbial community, even if an increase in soil microbial activity and biomass after sludge application (with higher doses than our study) has frequently been reported $[15,46,47]$. It is known that sludge amendment generally improves soil fertility and functionality in a dose-dependent manner [48]. However, in our study, an improvement of respiration rate and enzymatic activities following the addition of sewage sludge was not found.

Only soils amended with compost (alone or in combination with mineral fertilizers) showed higher enzymatic activities than the untreated and mineral fertilized soils, in agreement with other reports on the enhancement of hydrolytic enzymes by organic amendments $[49,50]$. The increased values of enzymatic activities may be related both to the amount of enzymes originally present in the materials and to "de novo" biosynthesis by soil microorganisms, which are stimulated by organic compounds in the added materials [51, 52]. Hydrolytic activity, in particular, estimates the total soil heterotrophic activity involving the use of a variety of substrates, such as esters, proteins and lipids [35] and it is regulated by the presence of substrates available and easily mineralized by microorganisms [53]. The increase in hydrolytic activity following the addition of compost would thus reflect a greater availability of organic compounds. Moreover, a significant increase in stable and total carbon in soil amended with compost has generally been found [54-56], allowing a maintenance of the microbial community with a slow release of nutrients. Sewage sludge also contains easily-degradable compounds [49] that could stimulate the synthesis of hydrolytic enzymes and their release from intracellular media into the soil, but only compost supported the activity along the six months of incubation.

Additionally, the highest phosphatase activity found after compost addition can be related to the highest SOM: several studies found a positive correlation between soil organic carbon and phosphatase activity $[57,58]$. A similar scenario was observed for $\beta$-glucosidase activity, in compost amended soils. In any case, differently from the other enzymatic activities, which progressively decrease along time in all the treatments (in relation to organic matter consumption), $\beta$-glucosidase increases after 4 months of soil incubation. This occurrence could be due to a greater release of this enzyme at a later time from incubation, when more recalcitrant organic compounds dominate, since a strong linkage of $\beta$-glucosidase to humus has been found in soils [49]. Organic compounds may have a complex structure and $\beta$-glucosidase can have a preferential immobilization in the humic substances, the most stable fraction of SOM. The increase in this activity after 4 months of incubation could also be related to a release of new organic matter to be degraded following the death of part of the microbial community, highlighted by the decrease in the microbial biomass recorded at the same sampling time. In particular, after three months of incubation, the increase in $\beta$-glucosidase activity could be linked to the use of the new necromass by the remaining microbial community. It is known that $\beta$-glucosidase activity is particularly sensitive to changes taking place in the system, providing advanced 
evidences of variations in organic matter long before they can be accurately measured by other routine methods $[59,60]$.

The increases in microbial biomass (microbial $\mathrm{C}$ and $\mathrm{N}$ ), respiration rate and enzymatic activities in soils treated with biowaste compost can be thus consequence of microbial growth, stimulation of microbial activity through greater availability of resources, as well as changes in the composition of the microbial community, due to the inoculum introduced. Furthermore, the improvement or stabilization of chemical (such as phosphorous concentrations) and physical properties of the soil $[31,60,61]$, can make the environment more favorable to microbial life.

The lack of any benefit following the amendment with sewage sludge is probably related to the amounts of sludge used in our experimentation-not enough to stimulate the microbial community. In addition, it must be taken into account that the quality of the organic matter in sludge depends on the matrix arriving at the plant. In the case of the Nocera UWWTP, the sludge comes from secondary sedimentation, and it is generally poorer in organic matter than that the sludge coming from primary sedimentation.

Despite the limited effects on the functional activity of the edaphic microflora, the amendment with sewage sludge (whose total metal concentrations are lower than the limit values established by the EU Directive 86/278/EEC [26] did not determine detrimental effects (as also in the case of biowaste compost), both in relation to total PTE concentrations and toxic effects on crops, assessed by germination tests. This observation ensures that detrimental effects (in relation to PTE concentrations and toxicity assays) did not result from the application of this kind of sewage sludge to agricultural soils, usually restricted by the potential environmental risks, deriving by the presence of toxic contaminants such as metals [47]. Even if for crop and ecosystem quality, bioavailable concentrations may be more relevant than total PTE concentrations [62], it should be considered that, on the one hand, SOM can reduce soil PTE bioavailabilities, due to the formation of metal-organic complexes [63]. On the other hand, a high $\mathrm{pH}$ is known to reduce the bioavailability of most PTEs in soil [64]. In our study, sewage sludge application slightly decreases soil pH, in agreement with other authors $[48,65]$, which could increase PTE bioavailabilities, an occurrence to be considered when studying the effects of different fertilization practices on crop quality.

In relation to PTE concentrations, microbial biomass results were negatively affected by soil $\mathrm{Ni}$ and $\mathrm{V}$ concentrations, as often reported in literature [66]. It is known that several PTEs such as $\mathrm{Cu}, \mathrm{Mn}$ and $\mathrm{Zn}$ are essential for microbes and plants, and are essential in maintaining soil functionality, but they can be a threat when present in high concentrations $[67,68]$. In this context, enzyme activities are not only important in sustaining the bio-geochemical cycles, but are excellent ecological indicators of soil quality [69,70], being greatly affected by soil type and toxic pollutant characteristics (i.e., most of them are reduced greatly by high heavy metal contamination) [70-73]. In particular, $\beta$-glucosidase activity is a quick indicator of soil contamination by PTEs, usually showing a reduction due to the exposure to heavy metals [72,74]. Among the studied enzymatic activities, only $\beta$-glucosidase resulted negatively correlated with Mn. However, the effects of PTEs on soil microbial biomass and activity are still controversial [75-77]. In our study, positive correlations have often been found between PTEs and biological parameters, highlighting their overall stimulating effects on the microbial community [78]. As expected, considering the involvement of phosphatase activity in the cycling of $P$ [36], the enzyme activity and the element concentration were positively correlated. Also hydrolase activity can mineralize organic $\mathrm{P}$ in the process of decomposition, but since it depends on several enzymes, it is involved in the degradation of a wide range of organic compounds [35].

\section{Conclusions}

This mesocosm study shows that, although the amendment with sewage sludge from secondary sedimentation does not provide any benefit, soil amendment with biowaste compost induces positive effects on both the concentration of soil organic matter, and mi- 
crobial biomass (assessed through microbial $\mathrm{C}$ and $\mathrm{N}$ ) and functionality (assessed through enzymatic activity and soil respiration). Indeed, all the biological parameters exhibited high average values only in soils amended with compost (alone or in combination with mineral fertilizers), indicating a positive effect of the added organic matter on microbial activity and, consequently, on soil biological quality. This is probably due both to the amount of added organic matter, improving the physiological response of the microbial community, and to a possible inoculation of microorganisms through the compost used. On the contrary, no differences for all the biological parameters were found in soils with added sewage sludge from secondary sedimentation, showing values comparable to mineral fertilized and untreated soils. This indicates that sewage sludge amendment, at the doses employed in our study, does not improve the soil biological quality and, consequently, the sustainability of agroecosystem productivity. Additionally, in the framework of sewage sludge use in agriculture, no detrimental effects (in relation to total PTE concentrations and toxicity assays) derived by the use of sludge coming from secondary sedimentation was observed, but regulations of the optimal quantities for each geographical area are needed.

Supplementary Materials: The following are available online at https:/ / www.mdpi.com/2071-1 050/13/1/26/s1, Figure S1 Mean values of $\mathrm{pH}$ in untreated soil (UNT), and in soils treated with biowaste compost (CMP), sewage sludge (FNG), compost plus mineral fertilizer $(C+M)$, sewage sludge plus mineral fertilizer $(\mathrm{F}+\mathrm{M})$ and mineral fertilizer (MIN) during 6 months of incubation. The error bars represent the standard deviations. Two way ANOVA F-values evaluated for $\mathrm{pH}$ are also shown; asterisks indicate significant $(p<0.001)$ differences; Figure S2 Mean values of PTE concentrations in untreated soil (UNT), and in soils treated with biowaste compost (CMP), sewage sludge $(F N G)$, compost plus mineral fertilizer $(C+M)$, sewage sludge plus mineral fertilizer $(\mathrm{F}+\mathrm{M})$ and mineral fertilizer (MIN) during 6 months of incubation. The error bars represent the standard deviations. Two way ANOVA F-values evaluated for the PTEs are also shown; asterisks indicate significant $(p<0.001)$ differences; Table S1 Treatments, abbreviations and doses used in the mesocosms setup; Table S2 Pearson coefficients and P values $\left({ }^{* * *} p<0.001,{ }^{* *} p<0.01,{ }^{*} p<0.05\right)$ of correlations between PTE concentrations and biological parameters.

Author Contributions: Conceptualization, D.B., G.L. (Giusy Lofrano) and M.C.; methodology, D.B. and E.P.; data acquisition, D.B., E.P., L.P. and G.L. (Giovanni Libralato); data analysis, E.P.; data curation, all authors; resources, D.B.; writing-original draft preparation, D.B. and E.P.; writingreview and editing, all authors. All authors have read and agreed to the published version of the manuscript.

Funding: This research was funded by the University of Salerno (ORSA130355).

Data Availability Statement: The data presented in the study are available in the figures, tables and Supplementary Materials accompanying the present article.

Conflicts of Interest: The authors declare no conflict of interest.

\section{References}

1. Davidson, E.A.; Janssens, I.A. Temperature sensitivity of soil carbon decomposition and feedbacks to climate change. Nat. Cell Biol. 2006, 440, 165-173. [CrossRef] [PubMed]

2. Nortcliff, S. Soil Erosion and Carbon Dynamics. In Advances in Soil Science; Roose, E.J., Lal, R., Feller, C., Barthes, B., Stewart, B.A., Eds.; CRC Press (Taylor and Francis): Boca Raton, Fl, USA, 2006; p. 352. ISBN 1-56670-688-9.

3. Wendling, B.; Jucksch, I.; Mendonça, E.D.S.; Neves, J.C.L.; Silva, I.R.; Da Costa, L.M. Organic-Matter Lability and Carbon-Management Indexes in Agrosylvopasture System on Brazilian Savannah. Commun. Soil Sci. Plant. Anal. 2008, 39, 1750-1772. [CrossRef]

4. Agency for Toxic Substances and Disease Registry Division of Toxicology and Human Health Sciences (ATSDR). Agency for Toxic Substances and Disease Registry Toxicological. Atlanta, GA 30329-4027. 2015.

5. Ren, X.; Zeng, G.; Tang, L.; Wang, J.; Wan, J.; Liu, Y.; Yu, J.; Yi, H.; Ye, S.; Deng, R. Sorption, transport and biodegradation-An insight into bioavailability of persistent organic pollutants in soil. Sci. Total. Environ. 2018, 1154-1163. [CrossRef] [PubMed]

6. Renzi, R.F.G. Spatial Analysis and Prediction of Soil Organic Carbon in Friuli Venezia Giulia Region (Northern Italy). Geoinform. Geostat. Overv. 2014, 2. [CrossRef]

7. Memoli, V.; De Marco, A.; Baldantoni, D.; De Nicola, F.; Maisto, G. Short- and long-term effects of a single application of two organic amendments. Ecosphere 2017, 8, e02009. [CrossRef] 
8. Morra, L.; Baiano, S.; Bilotto, M.; Bandantoni, D. The Replacement of Mineral Fertilizers with Biowaste Compost in a Seven-Year Experiment, Enhanced Vegetables Productivity, Soil Organic Carbon Content with minimum nitrate leaching Risk. In Proceedings of the 2nd International GRAB-IT Workshop, Capri Napoli, Italy, 27-29 June 2018; pp. 28-31.

9. Latare, A.; Kumar, O.; Singh, S.; Gupta, A. Direct and residual effect of sewage sludge on yield, heavy metals content and soil fertility under rice-wheat system. Ecol. Eng. 2014, 69, 17-24. [CrossRef]

10. Lloret, E.; Pascual, J.A.; Brodie, E.L.; Bouskill, N.J.; Insam, H.; Juárez, M.F.-D.; Goberna, M. Sewage sludge addition modifies soil microbial communities and plant performance depending on the sludge stabilization process. Appl. Soil Ecol. 2016, 101, 37-46. [CrossRef]

11. Singh, R.P.; Singh, P.; Ibrahim, M.H.; Hashim, R. Land Application of Sewage Sludge: Physicochemical and Microbial Response Land Application of Sewage Sludge: Physicochemical and Microbial Response. Environ. Contam. Toxicol. 2011, 214, 41-61. [CrossRef]

12. Baldantoni, D.; Saviello, G.; Alfani, A. Nutrients and non-essential elements in edible crops following long-term mineral and compost fertilization of a Mediterranean agricultural soil. Environ. Sci. Pollut. Res. 2018, 26, 35353-35364. [CrossRef]

13. Baldantoni, D.; Bellino, A.; Morra, L.; Alfani, A. Compost Amendment Enhances Natural Revegetation of a Mediterranean Degraded Agricultural Soil. Environ. Manag. 2015, 56, 946-956. [CrossRef]

14. Poulsen, P.H.; Abu Al-Soud, W.; Bergmark, L.; Magid, J.; Hansen, L.H.; Sørensen, S.J. Effects of fertilization with urban and agricultural organic wastes in a field trial—Prokaryotic diversity investigated by pyrosequencing. Soil Biol. Biochem. 2013, 57, 784-793. [CrossRef]

15. Roig, N.; Sierra, J.; Martí, E.; Nadal, M.; Schuhmacher, M.; Domingo, J.L. Long-term amendment of Spanish soils with sewage sludge: Effects on soil functioning. Agric. Ecosyst. Environ. 2012, 158, 41-48. [CrossRef]

16. Baldantoni, D.; Bellino, A.; Alfani, A. Soil compost amendment enhances tomato (Solanum lycopersicum L.) quality. J. Sci. Food Agric. 2016, 96, 4082-4088. [CrossRef] [PubMed]

17. Baldantoni, D.; Morra, L.; Saviello, G.; Alfani, A. Nutrient and toxic element soil concentrations during repeated mineral and compost fertilization treatments in a Mediterranean agricultural soil. Environ. Sci. Pollut. Res. 2016, 23, 25169-25179. [CrossRef]

18. Sort, X.; Alcan, J.M. Effects of sewage sludge amendment on soil aggregation. Land Degratation Dev. 1999, 12, 3-12. [CrossRef]

19. Singh, R.; Agrawal, M. Potential benefits and risks of land application of sewage sludge. Waste Manag. 2008, 28, 347-358. [CrossRef] [PubMed]

20. Bastida, F.; Jehmlich, N.; Martínez-Navarro, J.; Bayona, V.; García, C.; Moreno, J. The effects of struvite and sewage sludge on plant yield and the microbial community of a semiarid Mediterranean soil. Geoderma 2019, 337, 1051-1057. [CrossRef]

21. Petrie, B.; Barden, R.; Kasprzyk-Hordern, B. A review on emerging contaminants in wastewaters and the environment: Current knowledge, understudied areas and recommendations for future monitoring. Water Res. 2015, 72, 3-27. [CrossRef]

22. Epelde, L.; Becerril, J.M.; Kowalchuk, G.A.; Deng, Y.; Zhou, J.; Garbisu, C. Impact of Metal Pollution and Thlaspi caerulescens Growth on Soil Microbial Communities. Appl. Environ. Microbiol. 2010, 76, 7843-7853. [CrossRef]

23. Burges, A.; Epelde, L.; Garbisu, C. Impact of repeated single-metal and multi-metal pollution events on soil quality. Chemosphere 2015, 120, 8-15. [CrossRef]

24. Wang, Q.; Xiao, F.; He, T.; Wang, S. Responses of labile soil organic carbon and enzyme activity in mineral soils to forest conversion in the subtropics. Ann. For. Sci. 2013, 70, 579-587. [CrossRef]

25. Legislative Decree 75. Decreto Legislativo n. 75/2010 e Successiva Modifica del 10 luglio 2013. Aggiornamento Degli Allegati del Decreto Legislativo 29 aprile 2010 n. 75, Concernente il Riordino e la Revisione della Disciplina in Materia di Fertilizzanti; Italy, 2010 .

26. Council Directive. 86/278/EEC of 12 June 1986 on the Protection of the Environment, and in Particular of the Soil, When Sewage Sludge is Used in Agriculture. 1986; 1-10.

27. Legislative Decree 109. Disposizioni Urgenti per la Città di Genova, la Sicurezza della Rete Nazionale delle Infrastrutture e dei Trasporti, gli Eventi Sismici del 2016 e 2017, il Lavoro e le Altre Emergenze; Italy, 2018.

28. Barrutia, O.; Garbisu, C.; Epelde, L.; Sampedro, M.; Goicolea, M.; Becerril, J.M. Plant tolerance to diesel minimizes its impact on soil microbial characteristics during rhizoremediation of diesel-contaminated soils. Sci. Total Environ. 2011, 409, 4087-4093. [CrossRef] [PubMed]

29. Garbisu, C.; Alkorta, I.; Epelde, L. Assessment of soil quality using microbial properties and attributes of ecological relevance. Appl. Soil Ecol. 2011, 49, 1-4. [CrossRef]

30. Pardo, T.; Clemente, R.; Epelde, L.; Garbisu, C.; Bernal, M. Evaluation of the phytostabilisation efficiency in a trace elements contaminated soil using soil health indicators. J. Hazard. Mater. 2014, 268, 68-76. [CrossRef] [PubMed]

31. Iovieno, P.; Morra, L.; Leone, A.; Pagano, L.; Alfani, A. Effect of organic and mineral fertilizers on soil respiration and enzyme activities of two Mediterranean horticultural soils. Biol. Fertil. Soils 2009, 45, 555-561. [CrossRef]

32. Legislative Decree 86. Attuazione della direttiva 86/278/CEE concernente la protezione dell'ambiente, in particolare del suolo, nell'utilizzazione dei fanghi di depurazione in agricoltura. Gazz. Uff. Ser. Gen. 1992, 38, 1-34.

33. ARPA. Lombardia Elaborazione di Linee Guida per la Gestione dei Fanghi in Agricoltura. Committente: Regione Lombardia-DG Risorse Idriche e Servizi di Pubblica Utilità e Sviluppo Sostenibile. 2007.

34. Vance, E.; Brookes, P.; Jenkinson, D. An extraction method for measuring soil microbial biomass C. Soil Biol. Biochem. 1987, 19, 703-707. [CrossRef] 
35. Schnürer, J.; Rosswall, T. Fluorescein Diacetate Hydrolysis as a Measure of Total Microbial Activity in Soil and Litter. Appl. Environ. Microbiol. 1982, 43, 1256-1261. [CrossRef]

36. Dick, R.P.; Breakwell, D.P.; Turco, R.F. Soil Enzyme Activities and Biodiversity Measurements as Integrative Microbiological Indicators. In SSSA Special Publications; Wiley: Hoboken, NJ, USA, 2015; pp. 247-271.

37. Rodríguez-Loinaz, G.; Onaindia, M.; Amezaga, I.; Mijangos, I.; Garbisu, C. Relationship between vegetation diversity and soil functional diversity in native mixed-oak forests. Soil Biol. Biochem. 2008, 40, 49-60. [CrossRef]

38. EN Characterisation of Waste. Leaching. Compliance Test for Leaching of Granular Waste Materials and Sludges-Part 4: One Stage Batch at a Liquid to Solid Ratio of 10 1/ kg for Materials with Particle Size Below $10 \mathrm{~mm}$ (Without or With Size Reduction); 2002 (EN 12457-1-4).

39. ISO 8692:2012. Water Quality_Fresh Water Algal Growth Inhibition Test with Unicellular Green Algae; ISO: Geneva, Switzerland, 2012.

40. OECD. Test No.8: Terrestrial Plant Test: Seedling Emergence and Seedling Growth Test; OECD Publishig: Paris, France, 2006.

41. ISO. Determination of the Inhibition of the Mobility of Daphnia Magna Straus (Cladocera, Crustacea)—Acute Toxicity Test; ISO: Geneva, Switzerland, 2012.

42. R Core Team. A Language and Environment for Statistical Computing; R Foundation for Statistical Computing: Vienna, Austria, 2020.

43. Libralato, G.; Prato, E.; Migliore, L.; Cicero, A.; Manfra, L. A review of toxicity testing protocols and endpoints with Artemia spp. Ecol. Indic. 2016, 69, 35-49. [CrossRef]

44. Muñoz-Leoz, B.; Garbisu, C.; Antigüedad, I.; Ruiz-Romera, E. Fertilization can modify the non-target effects of pesticides on soil microbial communities. Soil Biol. Biochem. 2012, 48, 125-134. [CrossRef]

45. Kallenbach, C.; Grandy, A.S. Controls over soil microbial biomass responses to carbon amendments in agricultural systems: A meta-analysis. Agric. Ecosyst. Environ. 2011, 144, 241-252. [CrossRef]

46. Reardon, C.L.; Wuest, S.B. Soil amendments yield persisting effects on the microbial communities-a 7-year study. Appl. Soil Ecol. 2016, 101, 107-116. [CrossRef]

47. Mattana, S.; Petrovičová, B.; Landi, L.; Gelsomino, A.; Cortés, P.; Ortiz, O.; Renella, G. Sewage sludge processing determines its impact on soil microbial community structure and function. Appl. Soil Ecol. 2014, 75, 150-161. [CrossRef]

48. Hamdi, H.; Hechmi, S.; Khelil, M.N.; Zoghlami, I.R.; Benzarti, S.; Mokni-Tlili, S.; Hassen, A.; Jedidi, N. Repetitive land application of urban sewage sludge: Effect of amendment rates and soil texture on fertility and degradation parameters. Catena 2019, 172, 11-20. [CrossRef]

49. Bastida, F.; Jindo, K.; Moreno, J.L.; Hernandez, T.; Garcia, C.; Moreno, J.L. Effects of organic amendments on soil carbon fractions, enzyme activity and humus-enzyme complexes under semi-arid conditions. Eur. J. Soil Biol. 2012, 53, 94-102. [CrossRef]

50. Diacono, M.; Montemurro, F. Long-term effects of organic amendments on soil fertility. A review. Agron. Sustain. Dev. 2010, 30, 401-422. [CrossRef]

51. Ye, J.; Zhang, R.; Nielsen, S.; Joseph, S.D.; Huang, D.; Thomas, T. A Combination of Biochar-Mineral Complexes and Compost Improves Soil Bacterial Processes, Soil Quality, and Plant Properties. Front. Microbiol. 2016, 7. [CrossRef]

52. Antunes, L.P.; Martins, L.F.; Pereira, R.V.; Thomas, A.M.; Barbosa, D.; Lemos, L.N.; Silva, G.M.M.; Moura, L.M.S.; Epamino, G.W.C.; Digiampietri, L.A.; et al. Microbial community structure and dynamics in thermophilic composting viewed through metagenomics and metatranscriptomics. Sci. Rep. 2016, 6. [CrossRef]

53. Burns, R.G. Enzyme activity in soil: Location and a possible role in microbial ecology. Soil Biol. Biochem. 1982, $14,423-427$. [CrossRef]

54. Saviello, G.; Iovieno, P.; Morelli, R.; Baldantoni, D. Long-Term Compost Amendment of a Mediterranean Horticultural Soil. Part I: Relationships Among Biological and Chemical Soil Quality and the Yield of Two Crops Long-Term Compost Amendment of a Mediterranean Horticultural Soil. Part I: Relationships Amo. In Proceedings of the RAMIRAN Conference, Versailles, France, 3-5 June 2013.

55. Madejón, E.; Murillo, J.; Moreno, F.; López, M.; Arrue, J.; Álvaro-Fuentes, J.; Cantero-Martínez, C. Effect of long-term conservation tillage on soil biochemical properties in Mediterranean Spanish areas. Soil Tillage Res. 2009, 105, 55-62. [CrossRef]

56. Ros, M. Soil microbial activity after restoration of a semiarid soil by organic amendments. Soil Biol. Biochem. 2003, 35, 463-469. [CrossRef]

57. Dodor, D.E.; Tabatabai, M.A. Effect of cropping systems on phosphatases in soils. J. Plant Nutr. Soil Sci. 2003, 166, 7-13. [CrossRef]

58. Ghosh, A.; Singh, A.; Kumar, R.; Manna, M.; Bhattacharyya, R.; Rahman, M.M.; Sharma, P.; Rajput, P.; Misra, S. Soil enzymes and microbial elemental stoichiometry as bio-indicators of soil quality in diverse cropping systems and nutrient management practices of Indian Vertisols. Appl. Soil Ecol. 2020, 145, 103304. [CrossRef]

59. Makoi, J.H.J.R.; Ndakidemi, P.A. Selected soil enzymes: Examples of their potential roles in the ecosystem. African J. Biotechnol. 2008, 7, 181-191. [CrossRef]

60. Mpeketula, P.M.G.; Snapp, S. Structural Stability Conditions Soil Carbon Gains from Compost Management and Rotational Diversity. Soil Sci. Soc. Am. J. 2018, 83, 203-211. [CrossRef]

61. Saha, S.; Mina, B.; Gopinath, K.A.; Kundu, S.; Gupta, H.S. Organic amendments affect biochemical properties of a subtemperate soil of the Indian Himalayas. Nutr. Cycl. Agroecosyst. 2007, 80, 233-242. [CrossRef]

62. Alkorta, I.; Epelde, L.; Mijangos, I.; Amezaga, I.; Garbisu, C. Bioluminescent Bacterial Biosensors for the Assessment of Metal Toxicity and Bioavailability in Soils. Rev. Environ. Health 2006, 21, 139-152. [CrossRef] 
63. Mohapatra, D.P.; Cledón, M.; Brar, S.K.; Surampalli, R.Y. Application of Wastewater and Biosolids in Soil: Occurrence and Fate of Emerging Contaminants. Water Air Soil Pollut. 2016, 227, 1-14. [CrossRef]

64. Soler-Rovira, P.; Madejón, E.; Madejón, P.; Plaza, C. In situ remediation of metal-contaminated soils with organic amendments: Role of humic acids in copper bioavailability. Chemosphere 2010, 79, 844-849. [CrossRef]

65. Urra, J.; Alkorta, I.; Mijangos, I.; Epelde, L.; Garbisu, C. Application of sewage sludge to agricultural soil increases the abundance of antibiotic resistance genes without altering the composition of prokaryotic communities. Sci. Total. Environ. 2019, 647, 1410-1420. [CrossRef] [PubMed]

66. Giller, K.E.; Witter, E.; McGrath, S.P. Toxicity of heavy metals to microorganisms and microbial processes in agricultural soils: A review. Soil Biol. Biochem. 1998, 30, 1389-1414. [CrossRef]

67. Murtaza, G.; Usman, Y.; Niazi, N.K.; Usman, M.; Hussain, T. Bioaccumulation of Potentially Toxic Elements in Cereal and Legume Crops: A Review. CLEAN Soil Air Water 2017, 45. [CrossRef]

68. Dudka, S.; Miller, W.P. Accumulation of potentially toxic elements in plants and their transfer to human food chain. J. Environ. Sci. Heal. Part. B 1999, 34, 681-708. [CrossRef]

69. Alkorta, I.; Aizpurua, A.; Riga, P.; Albizu, I.; Amézaga, I.; Garbisu, C. Soil Enzyme Activities as Biological Indicators of Soil Health. Rev. Environ. Health 2003, 18, 65-73. [CrossRef]

70. Hu, X.-F.; Jiang, Y.; Shu, Y.; Hu, X.; Liu, L.; Luo, F. Effects of mining wastewater discharges on heavy metal pollution and soil enzyme activity of the paddy fields. J. Geochem. Explor. 2014, 147, 139-150. [CrossRef]

71. Su, C.; Jiang, L.; Zhang, W. A review on heavy metal contamination in the soil worldwide: Situation, impact and remediation techniques. Environ. Skept. Critics 2014, 3, 24-38.

72. Pattnaik, B.K.; Equeenuddin, S.M. Potentially toxic metal contamination and enzyme activities in soil around chromite mines at Sukinda Ultramafic Complex, India. J. Geochem. Explor. 2016, 168, 127-136. [CrossRef]

73. Ghosh, S.K. Waste Management and Resource Efficiency; Springer Science and Business Media LLC: Berlin, Germany, 2019.

74. Kucharski, J.; Boros, E.; Wyszkowska, J. Biochemical activity of nickel-contaminated soil. Polish J. Environ. Stud. 2009, 18, 1039-1044.

75. Kozdrój, J.; Van Elsas, J.D. Response of the bacterial community to root exudates in soil polluted with heavy metals assessed by molecular and cultural approaches. Soil Biol. Biochem. 2000, 32, 1405-1417. [CrossRef]

76. Renella, G.; Egamberdiyeva, D.; Landi, L.; Mench, M.; Nannipieri, P. Microbial activity and hydrolase activities during decomposition of root exudates released by an artificial root surface in Cd-contaminated soils. Soil Biol. Biochem. 2006, 38, 702-708. [CrossRef]

77. Lorenz, N.; Hintemann, T.; Kramarewa, T.; Katayama, A.; Yasuta, T.; Marschner, P.; Kandeler, E. Response of microbial activity and microbial community composition in soils to long-term arsenic and cadmium exposure. Soil Biol. Biochem. 2006, 38, 1430-1437. [CrossRef]

78. Memoli, V.; Eymar, E.; García-Delgado, C.; Esposito, F.; Panico, S.C.; De Marco, A.; Barile, R.; Maisto, G. Soil element fractions affect phytotoxicity, microbial biomass and activity in volcanic areas. Sci. Total. Environ. 2018, 636, 1099-1108. [CrossRef] [PubMed] 